DOI: https://doi.org/10.34069/AI/2021.45.09.27

How to Cite:

Hlebova, N., Afanasieva, L., Bukrieieva, I., Semikin, M., \& Orlov, A. (2021). Social solidarity and cohesion in the fight against the COVID-19 pandemic in intercultural cities. Amazonia Investiga, 10(45), 272-280. https://doi.org/10.34069/AI/2021.45.09.27

\title{
Social solidarity and cohesion in the fight against the COVID-19 pandemic in intercultural cities
}

\section{Соціальна солідарність та згуртованість у боротьбі з пандемією COVID-19 у міжкультурних містах}

Received: June 9, 2021

Accepted: August 29, 2021

\begin{abstract}
The study analyzes the impact of the COVID-19 pandemic on intercultural interactions. It considers the sociocultural mechanisms for ensuring cohesion and social solidarity in multicultural communities. The paper highlights the social contexts of the current problems of multicultural communities in overcoming intercultural barriers and the development of trust, social solidarity and cohesion. It reveals the direction of the main negative effects of the COVID-19 pandemic on the cohesion and development of social solidarity of multicultural communities. The successful international and domestic cases of counteraction of communities of intercultural cities against the COVID-19 pandemic are analyzed. The factors of development of social solidarity and cohesion of international and Ukrainian community in the conditions of pandemic are investigated. It has been found that social solidarity and cohesion of communities is an effective means of public counteraction to modern destructive factors and
\end{abstract}

Анотація

У дослідженні аналізується вплив пандемії COVID-19 на міжкультурні взаємодії. Він розглядає соціокультурні механізми забезпечення згуртованості та соціальної солідарності у полікультурних спільнотах. У статті висвітлюються соціальні контексти сучасних проблем мультикультурних спільнот у подоланні міжкультурних бар'єрів та розвитку довіри, соціальної солідарності та згуртованості. У ньому розкривається напрямок основних негативних наслідків пандемії COVID-19 на згуртованість та розвиток соціальної солідарності мультикультурних спільнот. Проаналізовано успішні міжнародні та внутрішні випадки протидії громад міжкультурних міст проти пандемії COVID-19. Досліджено фактори розвитку соціальної солідарності та згуртованості міжнародної та української спільноти в умовах пандемії. Було виявлено, що соціальна солідарність та згуртованість громад $\epsilon$ ефективним засобом протидії

\footnotetext{
108 Dr. Sc. in Sociology, Professor of Sociology Department, Bohdan Khmelnytsky Melitopol State Pedagogical University, Melitopol, Ukraine.

${ }^{109}$ Ph.D in Philosophical Sciences, Associate Professor of Sociology Department, Bohdan Khmelnytsky Melitopol State Pedagogical University, Melitopol, Ukraine.

${ }^{110}$ Ph.D in Philosophical Sciences, Associate Professor of Sociology Department Bohdan Khmelnytsky Melitopol State Pedagogical University, Melitopol, Ukraine.

${ }^{111}$ Ph.D in Philosophical Sciences, Associate Professor of Sociology Department Bohdan Khmelnytsky Melitopol State Pedagogical University, Melitopol, Ukraine.

112 Ph.D in Philosophical Sciences, Associate Professor of Sociology Department Bohdan Khmelnytsky Melitopol State Pedagogical University, Melitopol, Ukraine.
} 


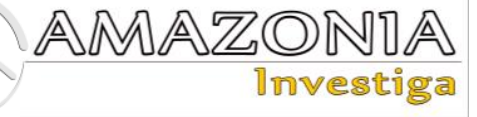

challenges. It is established that the communities of cities-participants of intercultural networks have developed effective mechanisms to maintain positive relations between people of different nationalities, religions, cultures and can serve as a positive example for other cities through the implementation of the model of ethnocultural diversity management.

Key words: social solidarity and cohesion, ethnocultural communities, COVID-19 pandemic.

\section{Introduction}

The Covid-19 pandemic has caused unprecedented individual, economic, and social damage to the humanity and has posed two opportunities to the world community: the danger of unprecedented collapse and the chance for social solidarity. It has become an exceptional problem in terms of nature and consequences, which causes a need for joint efforts at the global, interstate, state, and at the level of intercultural interaction and mutual assistance of all members of any community.

The multicultural cities are the most vulnerable to Covid-19. There some representatives often have limited access to the transparent and understandable information. Such situations often become a result of feeling a fear by members of these groups, when the inability to control the situation leads to the feelings of isolation, alienation, and inferiority. In these circumstances, it is important to use the experience of interethnic integration of successful communities, whose strategies and practices contribute to the achievement of mutual understanding and social cohesion of their members under pandemic conditions. Communities from different countries have to work together, learn from each other and coordinate their efforts to overcome intercultural barriers in order to avoid the risks as much as possible.

The social situation is extremely tense in the country and in the world, because every day we turn on the TV or turn the pages on social networks and we see terrible statistics and horrible details of the epidemic everywhere. Solidarity and cohesion are the best indicators of the fight against pandemic, because it cannot be overcome alone.

According to experts (Hebreisus, 2021; Patsek, 2020), the COVID-19 pandemic has caused us громадськості сучасним руйнівним чинникам та викликам. Встановлено, що спільноти міст-учасників міжкультурних мереж розробили ефективні механізми підтримки позитивних стосунків між людьми різних національностей, релігій, культур і можуть служити позитивним прикладом для інших міст шляхом реалізації моделі управління етнокультурним різноманіттям.

Ключові слова: соціальна солідарність та згуртованість, етнокультурні спільноти, пандемія COVID-19.

unprecedented individual, economic, and social damage. A pandemic is a test of humanity's ability to counter the threats of civilization in general, to organize to solve the urgent problems and draw the right conclusions, and to make the world interpenetrating.

The nature and scale of the problem actualize public and scientific interest both in identification of "stress markers" and in the search for systemic factors to increase social solidarity and cohesion in the countering the COVID-19 pandemic. In order to defeat the virus, communities, countries and our entire multicultural region must work together, learn from each other, and coordinate their efforts to achieve a high level of solidarity and cohesion.

Understanding the pandemic as a global problem is especially important for finding the foundations of social cohesion, as means of reducing the tensions and social solidarity of multicultural communities. The main goal is to learn better from each other and coordinate the efforts in the complex conditions of the COVID19 pandemic. There is small research on the pandemic in terms of its holistic understanding in domestic social and philosophical thought. That's why this paper is one of the first contributions to this urgent problem.

In our study, we will consider social cohesion as the involvement and participation of members of society in sociocultural life; as a sense of solidarity and belonging to society, based on the effective use of civil rights and aimed at achieving the well-being of the vast majority of citizens, harmonious and stable relations, overcoming the social isolation of activity.

The social solidarity seems a difficult concept to study. Nevertheless, researchers note its extreme importance in detailing the category of solidarity 
as a wide range of components: mutual aid, trust, perception of difference, perception of justice, social inclusion, etc. (Bondarenko, Babenko, \& Borovskyi, 2017:59).

The idea of social cohesion is one of the main directions of development of modern society and is based on the active participation of the population in solving current problems of life, overcoming social isolation and social disintegration. This concept is quite new. Its basic principles were set out only in 1990. That's why there is little research related to it.

The interest in the problem of social solidarity is usually associated with the ideas of Auguste Comte about social harmony (Comte, 1970), Emile Durkheim (Durkheim, 1982) about solidarity and shared loyalties, which unite the society, Talcott Parsons about social stability (Parsons, 1964).

Modern Ukrainian researchers - N. Amelchenko (Amelchenko, 2006), M. Bondarenko (Bondarenko, Babenko, \& Borovskyi, 2017), V. Kremen (Kremen, 2014), O. Shevchenko (Shevchenko, 2016), V. Zablotskyi (Zablotskyi, 2002) - connect solidarity processes with such modern phenomena as cooperation, cohesion, unity, public trust, the presence of common ideas, views, goals, belonging to a certain whole system in different aspects and at different levels of manifestations of this phenomenon: from solidarity of small groups to social solidarity of society as a whole, where solidarity is seen as one of the preconditions for stability and social order. Today, the Department of Social Cohesion has been established in Council of Europe; the results of the research of different aspects of social cohesion are reflected in the periodical "Trends in social cohesion"; published "Concerted development of social cohesion indicators: methodological guide" collective authorship of which belongs to the experts and practitioners (Council of Europe 2005).

Today social cohesion is interpreted as a quality of community or society. Cohesive communities include conflict-free, harmonious, stable communities, where are minimal differences and polarization between members. Such an approach to social cohesion puts the question of quality, the features of community or society, which allow them to be reduced, on the agenda.

The aim of our study is to analyze the essence of the factors that determine the processes of social solidarity and effective consolidation of efforts to overcome the pandemic.

\section{Methodology}

This study covered video, audio, images, media reports, posts on pages and social media groups highlighting the events connected with COVID-19 pandemic, reactions and public sentiment to these events, and successful international and domestic cases of counteracting the COVID-19 pandemic in intercultural cities (147 cities).

The content analysis procedures were used at the methodological level. They were followed by case study, during which samples ( 3 primary and 11 sub-samples) of messages and information materials were formed, categories and units of analysis were selected according to audience prevalence and coverage, frequency of mention and context. Within this context, the dynamics of attention to the message, modes of perception of messages (positive, negative, neutral) through the analysis of feedback and comments are studied. The Case study method traced and built logical connections between information sources, audiences, direct and indirect consumers of information and stakeholders, beneficiaries of the dissemination, impact and consequences of certain messages.

The analysis allowed us to analyze the policy models of intercultural integration of intercultural cities, which disseminated examples of best practices for effective diversity management, prevention and resolution of possible conflicts and the use of the benefits of diversity. This has identified the best ways to overcome intercultural misunderstandings and intercultural barriers and build trust, social solidarity and cohesion in society.

\section{Theoretical framework}

Solidarity processes as a means of public counteraction to the main challenges of today

The COVID-19 pandemic has confirmed that security remains a major value even in the $21 \mathrm{st}$ century. Humanity is ready to sacrifice the usual benefits of civilization without hesitation for it.

The new virus has not only claimed more and more lives, it has also shattered the illusion of stability in a global world that seemed so strong. The free movement of people, goods, and capital around the world stopped in a few days. Presidents talk about the military situation. The residents sweep away monthly food supplies. The virus has not only disrupted the well-being of many people, it has also stopped the processes 


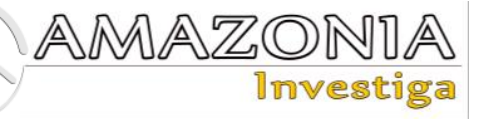

of globalization due to the threat of spreading the disease. All the plans of the society were insignificant in comparison with the main problem of the time - the protection of the country, city, and family.

There are certain objective social factors of one or another approach to the problem. First of all, it is the level of well-being. It is obvious that human losses among the population will be greater in the poorest countries without outside help. The events of last spring show that such developed democracies as Italy, Spain, Great Britain and other European countries failed to take the necessary measures that resulted heavy human losses. All these countries differ from Ukraine by greater transparency of management procedures and the role of public control. It is hard to say about the reasons of this tragedy: public openness and the complexity of restricting business freedoms or individual freedoms of citizen or any other factors. The inability or unwillingness of responsible officials of various departments or services to be extremely responsible for people's lives contributed to those consequences.

The social significance of both traditional media and new ones increased significantly during the pandemic, which raised many questions about the ethics of responsibility. Juggling figures, which push the limit for the introduction of quarantine, is not the first time to raise doubts about the existence of real figures for the spread of the virus in Ukraine, or about a legitimate suspicion of the side effects of such manipulations of public consciousness.

The constant confusion with information about the stock of beds for patients is incomprehensible to an objective observer. There is opacity or whitewash with the use of funds of the COVID19 Fund throughout Ukraine in regional media (depending on the affiliation of the media to the pro-government or opposition). The authorities' actions to block the borders where the carriers of the infection can enter during the quarantine period are extremely insufficient, and they worse the difficult situation. The situations hypothetically controlled by another approach turn into a situation of uncertainty in the absence of clarity and responsibility of officials at various levels. In particular, this violates the legitimate constitutional right of each individual to at least truthful information, or leads to the hopelessness of individual citizens in the worst case.

Inaccurate information to prevent coronavirus control, fabricated news hinders the global campaign against COVID-19. The UN is doing everything possible to prevent the spread of rumors, knowingly false reports, as well as statements that incite hatred and sow discord in society. United Nations Development Program, UNESCO, International Telecommunication Union (ITU), UN Global Pulse Initiative and the International Federation of Red Cross and Red Crescent Societies as part of the 75th session of the UN General Assembly called on the countries to develop and implement action plans to facilitate the timely dissemination of information based on scientific data and to prevent the dissemination of false information while respecting freedom of expression with the aim to draw attention to the crime involved with the dissemination of false information and deliberate misinformation.

The Secretary General of the Council of Europe Marija Pejčinović Burić and the Chair of the Committee of Ministers, Heiko Maas (Council of Europe, 2021) rightly point out that "the European Convention on Human Rights is a living tool for everyone to protect their rights, which helps us to deal with pandemic. Today, the Convention protects the rights of about 830 million people in Europe, including Ukrainians".

The Convention helps to ensure that any restrictions on our fundamental rights imposed by governments to help combat COVID-19 are necessary and proportionate to the threats we face. Our freedoms cannot be taken away at will. The Convention provides clear guarantees for our right to information about the pandemic and our freedom of speech - the freedom to speak openly about what we think about the problems we face, to disagree with those whose opinions differ, and to come together with others to have our voices heard more clearly (Council of Europe, 2020).

The pace and scale of the spread of COVID-19 is convincing evidence of how integrated and socially cohesive humanity is. Modern globalization has undeniable positive features. These are incentives for economic growth, virtually unlimited intercultural communication, and freedom of movement. It also has its dark sides, which are not talked about so willingly. Globalization increases the vulnerability of humanity, when regional disasters are rapidly becoming a universal disaster and threat. Ukrainian cities are experiencing an influx of internally displaced persons in the current, extremely difficult circumstances of life in the conditions of external aggression and occupation of the territories, in the conditions of the 
Ukrainian and European present. The problem of overcoming intercultural barriers in multinational cities is exacerbated along with the many complications associated with COVID-19. The social environment of multicultural cities is not only a center for meeting different ethnic groups, and the most dynamic space for the development of creative thought and innovation. It also accumulates the most complete palette of sociocultural, economic problems and contradictions.

\section{Social problems of multicultural communities in conditions of the COVID-19 pandemic}

The urgent self-isolation of countries, quarantine, deportation of foreigners and suspicious persons suddenly became a reality under the pressure of mass panic. The pandemic destroyed the usual way of life of millions of people. The important things of previous decades have devalued before our eyes in a couple of months: the consumer society has been transformed into a security society.

According to media and think tanks, quarantine measures introduced to limit the spread of the coronavirus have had the most negative impact on such vulnerable groups as members of certain ethnic groups, displaced persons / migrants, foreign students, and so on. It is not possible always to take into account all the factors of the situation due to certain complications. Those social classes that have a situational impact on the authorities and the power to impose restrictions are the least affected. This exacerbates inequalities and weakens social cohesion further (Council of Europe, 2021).

If we look at the situation at the household level, we will see many changes. People want to run away, hide and fence off. These shocks not only isolate them, but also make them afraid of even their own neighbors. There are outbreaks of xenophobia. People who have migrated to more developed countries in search of a better life are severely limited because they do not always have access to transparent and understandable information. Indigenous people often prejudice them with poor language skills, non-compliance with quarantine rules, and the spread of infection. Migrants will soon be perceived as a dangerous subject, almost a criminal, whose freedoms can and should be restricted or abolished.

The problem of people which have long been cut off from their homeland, native culture, language and daily life for various reasons is added to the above common problems related to the pandemic for Ukrainian and foreign multicultural communities. These are the specific problems of the most vulnerable groups and individuals from an intercultural perspective - settlers and migrants from the Middle East, Central Asia, Africa and Eastern Europe, who make up a significant proportion of the population of traditionally multicultural communities around the world today.

What is the role of intercultural dialogue, leadership, strategies, and participatory processes in effectively contributing to social inequality? What role do local authorities and their territories play? What processes are implemented in them in front of challenge? After all, Andriy Baumeister aptly notes, "we face two possibilities: the danger of collapse and the chance for social solidarity" (Polishchuk, 2020).

New challenges for our human rights, social, economic and institutional structures are already emerging today in addition to the immediate threat to health posed by the pandemic, with obvious consequences in all areas of our common daily reality.

Today, it is clear that the international community has been actively involved in preventing the negative sociocultural consequences of the pandemic despite all the obstacles. Urban space also carries all the problems, contradictions and opportunities that humanity and nations face and discover in the 21 st century. The processes taking place in the urban environment today raise a number of questions: how to strengthen the shared vision, cooperation, sense of belonging and participation of citizens both during and after the blockade and physical distancing? How to inform that processes are key and they take time and resources to achieve the results? How do we reorganize our societies to take advantage of intercultural potential in the post-pandemic era, what do we need to do differently? What new institutions, systems and infrastructures should be involved?

\section{Results and discussion}

This requires a common consideration of how the coronavirus can affect global processes, whether the tests of the crisis are unequivocally negative, whether there is a chance for a new understanding of solidarity and the strengthening of humanistic values, and what lessons we must learn in the future. And in such difficult conditions of today, the cities-participants, embodying models of management of 


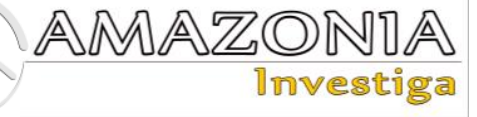

ethnocultural diversity, serve as a positive example for other cities to build positive relations between people of different nationalities, religions and cultures. Although exceptional situations require exceptional action, it is equally important to ensure that democracy and human rights, solidarity and cohesion regain a leading role in our multicultural urban communities.

In addition, it is obvious that intercultural strategies, which are implemented in many cities, allow their residents to find their way to the transition from "mine" to "our" city and open it to other cultures. The introduction of innovative intercultural practices (cases) ultimately benefits not only the network of intercultural cities, but also all multicultural communities. That is why it is so important now to take into account the urban model of intercultural integration, which is honestly tested, edited and recognized as effective by many cities participating in the Program of economic, social and ethnocultural integration of its inhabitants to overcome common threats and create the appropriate living conditions for the residents and representatives of ethnic and religious communities in the sociocultural space.

At the same time, we have considered the successful cases on overcoming intercultural barriers. These cases promote social solidarity and cohesion, give every reason to hope that limitation the quarantine measures would turn out the pandemic and everything directly related to it were only as a reflection and accelerator of real profound changes in the consciousness of multicultural communities. We will see the desire for intercultural dialogue and openness with the desire of all peoples to preserve and protect their identity and independence.

\section{Positive practices of multicultural communities in response to the Covid-19 pandemic}

It is important to think critically, to think together about how pandemic can affect European integration, whether the crisis is clearly negative, whether there is a chance to renew European solidarity and strengthen European values in these difficult times for the whole world.

Today, the Intercultural Cities Programme of the Council of Europe is a practical embodiment of these issues (Council of Europe, 2007, nd). An intercultural city is a community where cultural diversity is considered a value and the principles of mutual understanding, mutual respect and equality prevail (Afanasieva, \& RubikondoKhovanova, 2015:15). Currently, 176 cities around the world apply the urban model of intercultural integration, including cities not only in Europe but also in Australia, Japan, Africa, Mexico, Canada and the United States. More than 50 cities are part of the international network of ICC. National networks exist in Italy, Morocco, Norway, Portugal, Spain, Ukraine (Melitopol, Vinnytsia, Lutsk, Odessa, Pavlograd, Sumy).

The Intercultural Cities Programme not only seeks to expand and deepen the discussion of the problems of multicultural communities, but also to find the ways to solve them in the daily social solidarity of representatives of different ethnocultural groups and indigenous peoples. This makes it possible to blur significantly the ethnocultural boundaries between "majority" and "minorities", which greatly contributes to the mutual enrichment of "dominant" and subcultures, localities, classes, religions, disciplines and trends, and serves as a source of cultural, social, public and economic innovation in these communities. The practice of these communities confirms that the modern city is a dynamic environment that can change depending on the existing factor conditions, both external and internal. The active practices of intercultural cities became an example of the response of this situation in communities where ethnocultural diversity is the norm (Afanasieva, \& RubikondoKhovanova, 2015:15).

The efforts of volunteers from the Reggio Emilia city community (Italy) are the prominent examples of this work, where all information about Covid has been translated into the main languages of migrants and daily contacts with the most vulnerable sections of the community through WAPP are maintained. The Erlangen community (Germany) has created a special pandemic information page. The page is available in many languages, has an automatic tool for listening to content by people who cannot accept written content. A video channel has also been set up, where information is provided on a regular basis.

The City of Lublin (Poland) has created a special Covid-19 page on the website with current materials in English and Ukrainian, which is the most common minority language in the country. Oslo (Norway) has created an online information page in various languages. The municipality also supports NGOs working with vulnerable minority groups by providing them with special information posters and social media campaigns. The community of the city of Montreal (Canada) has begun to develop information and media 
campaign to disseminate the necessary information about the current situation among ethnocultural communities and immigrants through various means adapted to this target group. Four communication topics were identified: access to housing; food aid; rights and state aid; public health care instructions. (Council of Europe, 2007)

Melitopol (Ukraine) involved children of different nationalities in the creation of the video "Stay at home". Children raise awareness about the affairs of their communities, share games for children and adults in leisure time during quarantine thanks to the city's common website. The video is the result of cooperation between the city community, local schools, the Greek Society of Melitopol, the Jewish community, the Crimean Tatar Committee, the Ukrainian-Polish Society of Melitopol "Poloniia", the Center of Mexican Culture "Estrea" and representatives of other ethnic groups and communities.

Online meetings of city government and civil society organizations were organized to address the most important issues facing people of different cultural backgrounds and migrant communities in Sumy (Ukraine) and Limassol (Cyprus).

The city council of the multicultural city of Leeds (UK), which speaks more than 130 languages, has released 3 short films with basic tips on preventing and taking action on Covid-19 symptoms to ensure accurate distribution of key Public Health England messages to communities. These videos have been translated into 11 of the city's most common languages (Polish, Romanian, Urdu, Arabic, Czech, Punjabi, Tigrinya, Farsi, Slovak, Kurdish, Sorani and Bengali).

In Dublin (Ireland), Covid-19 INFO is a link created by the city council for people who may find it difficult to access information because English is not their first language. Active links lead users to information in their native language.

The city of Cartagena (Spain) promptly disseminates accurate information about the state of alarm announced by the Spanish government to families, organizations and mosques in Arabic, English and French. Coordination with the health sector is also ongoing to facilitate mediation for migrants so that there are no difficulties in understanding special emergency rules.

The above examples show that the response to the situation is quite adequate for civilized communities. Although the world was not ready for such a challenge, the ordinary lives of many people not only became more complicated, but began to change for the worse as never before. This was often influenced by the national and world media, not always well-thought-out urgent government decisions, or the position of the World Health Organization and other international organizations that were formed in the wake of the situation. The cities-participants of intercultural networks embody models and mechanisms for managing ethnocultural diversity, gain experience that can and should be a positive example for building a higher level of relations between representatives of different nationalities, religions and cultures of other multicultural cities in such difficult conditions today.

This also indicates another extremely important thing. Urban communities have significant potential to create the intercultural public space of modern cities in a digital globalized society, even weakened by the sanitary and economic crisis. Intercultural strategies, which are implemented in many cities, allow many of their residents to find their way to the transition from "my" to "our" city and open it to other cultures. That is why it is so important to take into account the urban model of intercultural integration to overcome common threats, as well as to provide city residents, refugees, migrants and ethnic communities with appropriate living conditions in the socio-cultural space (Afanasieva, \& Rubikondo-Khovanova, 2015).

The successful cases we have considered in overcoming intercultural barriers promote social solidarity and cohesion. They give every reason to hope that it turns out to be the pandemic and everything directly related to it in the social context only a reflection and accelerator of real profound changes in the minds of multicultural communities after quarantine measures are curtailed or limited. We will see the desire for intercultural dialogue and openness along with the desire of all peoples to preserve and protect their separateness, identity and independence.

\section{Conclusions}

Thus, the concept of cohesion and social solidarity can be stated in the context of the challenges associated with the problem of COVID-19 from a philosophical point of view. This covers a wide range of social problems. Their solution determines cohesion and stability of society. 


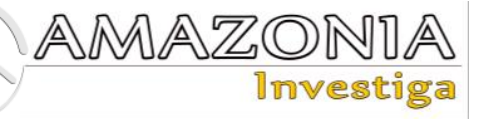

The analysis of successful cases gives grounds to believe that the intercultural factor can become the basis for building the urban social communications, active forms of interaction and dialogue, solidarity relations of members of the urban community. That is why it is so important to take into account the urban model of intercultural integration implemented by the cities-participants of the Intercultural Cities Programme of the Council of Europe to overcome common threats of selfishness, indifference and even panic, as well as to find appropriate resources of international cooperation, ensuring the conditions of living in sociocultural space, which will promote social solidarity and cohesion.

Civic activity is the activity which social solidarity is most manifested in. Active public participation is a meaningful indicator of cohesion and contributes to the spread of social justice, efficiency of state and public services, development of democratic society. This requires purposeful activity and active involvement of individuals and groups in the process of civic and political participation. Unlike public participation, social participation represents the collective activity of people, the horizontal activity carried out by them within the framework of everyday life and aimed at satisfying the public interest.

Solidarity and cohesion are the best indicators of the fight against a pandemic, because it cannot be overcome alone. It is equally important to ensure leading role of democracy and human rights, solidarity and cohesion in our societies because exceptional situations require exceptional action. "And even the best vaccine will not help here... We need a vaccine of human love and charity" (Korotkyi, 2020).

Solidarity and cohesion in overcoming the pandemic cannot be imposed, nor can the spirit of patriotism and respect for the state be imposed or nurtured through various appeals and declarations. Ukraine can win the trust of its citizens and actively involve them in building a democratic civil society only by sensible policy, firmness and persistence in affirming the rights and freedoms of citizens and fundamental values of modern civilization, professionalism in solving problems.

\section{Bibliographic references}

Afanasieva, L., \& Rubikondo-Khovanova, K. (2015). Intercultural city as a model of integration of Ukrainian communities into the modern European space. Ukrainoznavchi almanac, 18, 14-17. Retrieved from: https://ukralmanac.univ.kiev.ua/index.php/u a/article/viewFile/2/103/ Accessed August 1, 2021.

Amelchenko, N. (2006). Thematization and problematization of solidarity of Ukrainian society in political and intellectual discourses. Ukrainian intellectuals: a view from the present. Kyiv: vydavnytstvo "Delta", 194-205.

Bondarenko, M., Babenko, S., \& Borovskyi, O. (2017). Social cohesion in Ukraine (experience of application of the method of bertelsmann stiftung to the data of European social research). Visnik Kivskoho National University named after Taras Shevchenko. Sociology, 1(8), 58-65.

Comte, A. (1970). Introduction to Positive Philosophy. Indianapolis: Bobbs-Merrill, 70

Council of Europe (2005). Concerted development of social cohesion indicators: methodological guide. Strasbourg: Cedex, $234 . \quad$ Retrieved from: https://book.coe.int/en/social-co-operationin-europe/8203-concerted-development-ofsocial-cohesion-indicators-methodologicalguide- book-cdrom.html/ Accessed August 1, 2021

Council of Europe (2007). Intercultural cities programme. Retrieved from: https://www.coe.int/en/web/interculturalcitie s/ Accessed August 1, 2021

Council of Europe (2020). European Convention on Human Rights. Strasbourg: Cedex, 234. Retrieved from: https://www.echr.coe.int/documents/convent ion_eng.pdf/ Accessed August 1, 2021

Council of Europe (2021). Intercultural Cities: COVID-19 Special page. Retrieved from: https://www.coe.int/en/web/interculturalcitie s/covid-19-special-page/ Accessed August 1, 2021

Council of Europe (2021) Statement by the Secretary General of the Council of Europe Marija Pejčinović Burić and Chair of the Committee of Ministers of the Council of Europe Heiko Maas. Retrieved from: https://www.coe.int/ru/web/portal/-/europeday-5-may-2021-72nd-anniversary-ofcouncil-of-europe Accessed September 12, 2021

Durkheim, E. (1982). The Rules of Sociological Method, N. Y.: The free press, 261

Hebreisus, T.A. (2021). The head of the World Health Organization Hebreisus stated the need for a new global agreement to combat pandemics. Espreso. Retrieved from: https://espreso.tv/news/2021/02/19/ochilnyk 
_vooz_gebreisus_zayavyv_pro_neobkhidnist _novoyi_globalnoyi_ugody_z_protydiyi_pa ndemiyam/ Accessed August 1, 2021

Korotkyi, V. (2020). The vaccine itself is not enough. We need sensitivity and solidarity. Ukrinform. Retrieved from: https://www.ukrinform.ua/rubricsociety/3156535-samoi-vakcini-zamalopotribni-cujnist-i-solidarnist.html/ Accessed August 1, 2021

Kremen, V. (2014). Consolidation paradigm of modernization of Ukraine. Svitohliad, 5, 49, 8-16

Parsons, T. (1964). The Social System, N. Y.: The free press, 575

Patsek, B. (2020). The threat is greater than nuclear war. Zbruc. Retrieved from: https://zbruc.eu/node/101547/ Accessed August 1, 2021

Polishchuk, A. (2020). "What awaits us after ...". Den, 56-57. Retrieved from: https://day.kyiv.ua/uk/article/podrobyci/shch o-chekaye-na-nas-pislya/ Accessed August 1, 2021

Popovych, I., Shevchenko, A., Galvez, L. M., \& Klenina, K. (2020). Estudio de la relación entre la deseabilidad social y las orientaciones valorativas de los jóvenes. Revista Notas Históricas y Geográficas, 26, 241-268

Shevchenko, O. (2016). Philosophical and political understanding of the concept of solidarity. Philosophical and Methodological Problems of Law, 1, 11, 83-91. Retrieved from:

https://philosophy.naiau.kiev.ua/index.php/p hilosophy/article/download/384/386/

Accessed August 1, 2021

Zablotskyi, V. (2002). Solidarity. Philosophical Encyclopedic Dictionary. Kyiv: Institute of Philosophy named after Chronoriy Skovoroda NAS of Ukraine, 372-377 